\title{
ANALISIS FAKTOR YANG MEMPENGARUHI WORD OF MOUTH AYAM GEPREK DON
}

\author{
Albertus Bobby Widagdo \\ Program Studi Magister Manajemen Universitas Tarumanagara \\ bobbyalbertus14@gmail.com \\ Yanuar \\ Program Studi Magister Manajemen Universitas Tarumanagara
}

Masuk : 06-06-2020, revisi : 26-06-2020 diterima untuk diterbitkan : 26-06-2020

\begin{abstract}
This study aims to examine the effect of brand image, brand trust and customer satisfaction on customer loyalty and its influence on product word of mouth. The data in this study were obtained from the results of filling in the questionnaire by 110 respondents who were all customers of Ayam Geprek Don products located in South Jakarta. Data from the questionnaire filling in this study were further analyzed using the Partial Least Square technique with the help of the SmartPLS program. Based on the results of the analysis in this study, some conclusions are obtained as follows: brand image, brand trust, and customer satisfaction have a positive and significant effect on loyalty. Then, loyalty has a positive and significant effect on product word of mouth. In general, the better the brand image and product brand trust and the higher the customer satisfaction, the higher loyalty which will further increase the positive word of mouth of the brand.
\end{abstract}

Abstrak: Penelitian ini bertujuan untuk menguji pengaruh citra merek, kepercayaan merek, dan kepuasan pelanggan terhadap loyalitas, serta pengaruhnya terhadap word of mouth produk. Data dalam penelitian ini diperoleh dari hasil pengisian kuesioner oleh sebanyak 110 responden yang seluruhnya adalah pelanggan produk Ayam Geprek Don yang berlokasi di Jakarta Selatan. Data hasil pengisian kuesioner dalam penelitian ini selanjutnya dianalisis dengan menggunakan teknik Partial Least Square dengan bantuan program SmartPLS. Berdasarkan hasil analisis dalam penelitian ini, diperoleh beberapa kesimpulan yaitu: citra merek, kepercayaan merek, dan kepuasan pelanggan berpengaruh positif dan signifikan terhadap loyalitas. Serta loyalitas berpengaruh positif dan signifikan terhadap word of mouth produk. Secara umum, semakin baik citra merek dan kepercayaan merek serta semakin tinggi kepuasan pelanggan, maka semakin tinggi loyalitas yang selanjutnya akan meningkatkan word of mouth positif dari merek.

Keywords: Brand Image, Brand Trust, Customer Satisfaction, Loyalty, Word of Mouth, Partial Least

\section{PENDAHULUAN \\ Latar Belakang}

Ayam Geprek Don merupakan salah satu rumah makan yang berada di Pondok Pinang Jakarta Selatan. Terdapat berbagai faktor yang mempengaruhi keputusan pembelian kembali produk tersebut. Konsep citra merek, kepercayaan merek, dan kepuasan pelanggan memiliki andil besar dalam menciptakan loyalitas. Jika terbentuk loyalitas di kalangan masyarakat niscaya terbentuk word of mouth yang positif pula terhadap suatu produk. Penulis mengasumsikan jika suatu restoran atau produk makanan cepat saji sudah mencapai titik di mana produk tersebut memiliki citra merek, kepercayaan merek, dan kepuasan pelanggan yang baik, maka dapat mempengaruhi loyalitas yang berdampak pada faktor word of mouth produk 
tersebut. Berdasarkan pemaparan latar belakang di atas, maka penulis tertarik untuk menyusun penelitian tesis dengan judul: “Analisis Faktor Yang Mempengaruhi Word Of Mouth Ayam Geprek Don"

\section{Tujuan Penelitian}

Penelitian ini bertujuan untuk: (1) mengetahui pengaruh citra merek (brand image) terhadap loyalitas merek Ayam Geprek Don; (2) Mengetahui pengaruh kepercayaan merek (brand trust) terhadap loyalitas merek Ayam Geprek Don; (3) Mengetahui pengaruh kepuasan pelanggan (customer satisfaction) terhadap loyalitas merek Ayam Geprek Don dan (4) Mengetahui pengaruh loyalitas merek terhadap word of mouth Ayam Geprek Don.

\section{KERANGKA TEORITIS Landasan Teori}

Brand Image. Citra merek juga dapat didefinisikan sebagai persepsi akan organisasi yang direfleksikan dalam asosiasi pada memori konsumen (Lee \& Jee, 2016). Hamza \& Rahul (2017) menyatakan jika citra dari suatu produk dalam pikiran konsumen merupakan brand image. Citra merek dilihat sebagai alasan atau persepsi emosional konsumen yang terasosiasi pada merek tertentu (Ali, Xiaoling, dan Sherwani, 2018).

Kepercayaan Merek. Kepercayaan merek dapat diartikan; ketika masalah yang tidak diinginkan terhadap produk muncul, maka pelanggan dapat tetap memiliki intensi yang baik terhadap merek tersebut jika mereka memiliki kepercayaan akan merek itu (Delgado dalam Krom, 2015). Krom (2015) juga menegaskan bahwa kepercayaan merek terdiri atas konsep seperti kualitas produk, pertemuan kebutuhan pelanggan, pendukung, konsistensi, dan kejujuran. Kedalaman hubungan antara perusahaan dan pelanggan meningkatkan potensi pelanggan dalam membagikan informasi privat dan rahasianya dengan merek. Selanjutnya, informasi tersebut dapat digunakan dalam pengembangan produk dan jasa di mana awalnya perusahaan tidak produksi dan pertimbangkan (Krom, 2015).

Kepuasan Pelanggan. Kepuasan pelanggan adalah cara seseorang merasakan setelah membandingkan perceived performance dari suatu produk berdasarkan ekspektasinya (Kotler dalam Krom, 2015). Konsep dari kepuasan pelanggan terbentang dari pertemuan kebutuhan dan ekspektasi pelanggan. Krom (2015) menjelaskan bahwa kepuasan pelanggan timbul dengan evaluasi dari suatu produk atau jasa dalam konteks variabel seperti kualitas dan performa. Melalui hal tersebut, kepuasan ataupun ketidakpuasan pelanggan berkembang melalui perbandingan ekspektasi dan persepsi pelanggan. Kepuasan pelanggan timbul di suatu titik di mana manfaat tersedia dari produk atau jasa yang dipilih dan bertemu dengan ekspektasi pelanggan (Krom, 2015).

Loyalitas. Loyalitas merek dapat didefinisikan sebagai kemungkinan relatif dari konsumen berpindah dari suatu merek dalam kasus di mana terdapat perubahan fitur produk, harga, ataupun kualitas. Jika loyalitas akan merek meningkat, pelanggan akan meresponnya dengan dengan tidak berpindah pada kompetitor (Upamannyu \& Mathur, 2012). Perusahaan dengan pelanggan setia akan memiliki tingkat penjualan yang lebih baik, upaya pemasaran yang lebih rendah, dan harga yang lebih baik. Hal ini dikarenakan pelanggan yang setia akan kecil kemungkinan untuk beralih ke merek lain, karena mereka mempercayai merek tersebut memiliki nilai unik yang tidak didapat pada merek kompetitor (Upamannyu \& Mathur, 2012). Word of Mouth. WOM dapat didefinisikan sebagai hal informal, person to person communication antara komunikator non komersial, dan penerima suatu merek, produk, ataupun jasa (Harris-Walker dalam Choi \& Choi, 2014). Di sisi lain dapat dilihat jika konsumen puas akan suatu produk atau jasa maka akan dengan mudah menyebarkan WOM seperti dalam bentuk rekomendasi (De Matos \& Rossi dalam Choi \& Choi, 2014). Baik pengalaman positif atau negatif akan suatu merek dapat menyebabkan pengaruh pada penyebaran WOM setelah pembelian (Choi \& Choi, 2014). 


\section{Kerangka Pemikiran}

\section{Hipotesis}

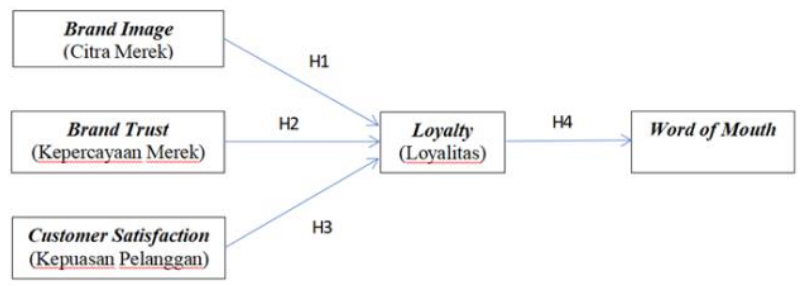

\section{Gambar 1 \\ Kerangka Pemikiran}

Sumber: Ilustrasi pribadi (2020)

Berdasarkan kerangka model yang dibangun dalam penelitian ini, maka hipotesis yang akan diuji dalam penelitian ini adalah sebagai berikut:

H1 : Brand Image berpengaruh terhadap Loyalitas Pelanggan

H2 : Brand Trust berpengaruh terhadap Loyalitas Pelanggan

H3 : Customer Satisfaction berpengaruh terhadap Loyalitas Pelanggan

H4 : Loyalitas berpengaruh terhadap Word of Mouth

\section{METODOLOGI PENELITIAN}

Populasi dan Sampel. Populasi dalam penelitian ini adalah pelanggan Ayam Geprek Don yang tinggal di sekitar Pondok Pinang, Jakarta Selatan (dekat lokasi gerai) dengan minimal usia 17 tahun. Dengan teknik probability sampling dan perhitungan jumlah minimal sampel menurut Hair, dkk. (2014), maka jumlah sampel yang digunakan dalam penelitian ini adalah sebanyak 110 responden.

Teknik Pengambilan Data. Data dalam penelitian ini diperoleh dari hasil pengisian kuesioner. Kuesioner yang digunakan berskala likert 1-5 (1 = Sangat tidak setuju, 2= Tidak setuju, $3=$ Netral, 4=Setuju, 5= sangat setuju). Kuesioner yang digunakan yang telah melalui tahap uji coba dan telah dinyatakan valid dan reliabel dalam mengukur variabel penelitian.

Teknik Analisa Data. Data dalam penelitian ini dianalisis dengan menggunakan teknik analisis deskriptif, dengan menggunakan teknik analisis PLS (Partial Least Square). Pada tahap pengujian outer model, validitas dan reliabilitas konstruk diuji. Indikator dinyatakan valid jika nilai loading factor > 0,7, AVE > 0,5, akar kuadrat AVE lebih besar dari korelasi antar variabel laten dan konstruk dinyatakan reliabel jika Cronbachs alpha $>0,7$ dan composite reliability $>0,7$. (Ghozali, 2016). Selanjutnya pada pengujian inner model PLS $<$ goodness of fit model terlebih dahulu diuji dengan melihat nilai SRMR model, model dinyatakan fit jika SRMR model $<0,08$ (perfect fit) dan apabila SRMR $<0,10$ dinyatakan fit. Setelah model dinyatakan fit, pengujian hipotesis dilakukan dengan melihat nilai $p$ value dan $T$ statistik, $p$ value $<0,05$ dan $T$ statistik $>$ 1,96 menunjukkan bahwa hipotesis nul ditolak sehngga menerima hipotesis yang diajukan dalam penelitian ini.

\section{HASIL}

\section{Deskripsi Responden}

Jumlah responden dalam penelitian ini adalah sebanyak 110 responden yang didominasi oleh pelanggan Ayam Geprek Don yang berjenis kelamin perempuan (57,3\%), berusia $21-40$ tahun (50\%), berpendidikan SMA, D3 dan S1 (77\%), bekerja sebagai wiraswasta, karyawan swasta dan profesional (77\%) dan memiliki pengeluaran 2-3 juta rupiah per bulan (44\%).

\section{Deskripsi Variabel}

Hasil analisis deskriptif terhadap masing-masing variabel dalam penelitian ini menunjukkan bahwa menurut persepsi sebagian besar responden menilai bahwa produk ini telah memiliki brand image yang baik, dipercaya sebagai produk yang jujur, aman dikonsumsi dan dapat diandalkan, dan dapat memberikan kepuasan yang tinggi kepada pelanggannya. 
Hasil analisis menunjukkan bahwa loyalitas terhadap Ayam Geprek Don cenderung tinggi, sehingga mereka akan membeli kembali, berniat untuk tetap membeli, berkomitmen, dan tetap ingin membeli produk dari Ayam Geprek Don walaupun harganya lebih mahal daripada produk ayam geprek sejenis. Memiliki WOM yang cenderung tinggi, sebagian besar pelanggan Ayam Geprek Don dengan senang hati menyebarkan keunggulan positif, akan merekomendasikan ke kerabat dan akan memberitahu kerabat untuk membeli produk dari Ayam Geprek Don di saat mencari produk ayam geprek.

\section{Hasil Analisis PLS}

\section{Pengujian Outer Model}

Hasil pengujian outer model dalam penelitian ini menunjukkan bahwa seluruh indikator telah memenuhi kriteria validitas konvergen dan deskriminan yang dipersyaratkan, dibuktikan dengan hasil pengujian outer model yang menunjukkan bahwa nilai loading factor seluruh indikator $>0,7$ dan AVE > 0,5, seluruh konstruk dalam model juga dinyatakn reliabel terbukti dari nilai Cronbachs alpha > 0,7 dan composite reliability > 0,7 (Ghozali, 2016).

\section{Pengujian Inner Model}

Hasil pengujian inner model menunjukkan bahwa nilai SRMR model yang diperoleh adalah sebesar 0,056 pada saturated model dan 0,071 pada estimated model menunjukkan bahwa model PLS berada pada kriteria perfect fit (Ghozali, 2016), sehingga layak digunakan untuk menguji hipotesis dalam penelitian ini. Hasil pengujian inner dapat dilihat pada model pada Gambar 2.

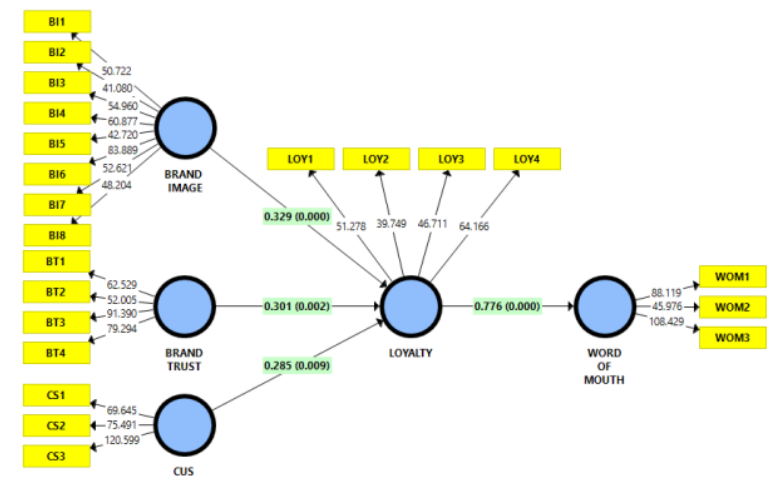

Gambar 2

Hasil Estimasi Model PLS

Sumber Data diolah peneliti (2020)

Tabel 1

Hasil Pengujian Inner Model

Path (Jalur)

Original Sample Standard Sample (O) Mean (M) $\begin{aligned} & \text { Deviation } \\ & \text { (STDEV) }\end{aligned}$

\begin{tabular}{|c|c|c|c|c|c|}
\hline \multicolumn{6}{|l|}{ Direct Effect } \\
\hline Brand Image $\rightarrow$ Loyalty & 0,329 & 0,344 & 0,077 & 4,289 & 0,000 \\
\hline Brand $\operatorname{Tr} \rightarrow$ Loyalty & 0,301 & 0,293 & 0,098 & 3,078 & 0,002 \\
\hline Brand Image $\rightarrow$ Loyalty & 0,285 & 0,280 & 0,109 & 2,630 & 0,009 \\
\hline Brand Image $\rightarrow$ Loyalty & 0,776 & 0,777 & 0,050 & 15,561 & $\mathbf{0 , 0 0 0}$ \\
\hline \multicolumn{6}{|l|}{ Indirect Effect } \\
\hline BI $>$ LOY $->$ WOM & 0,255 & 0,267 & 0,063 & 4,066 & $\mathbf{0 , 0 0 0}$ \\
\hline BT $->$ LOY $->$ WOM & 0,233 & 0,228 & 0,078 & 2,975 & $\mathbf{0 , 0 0 3}$ \\
\hline CUS -> LOY $->$ WOM & 0,221 & 0,218 & 0,086 & 2,579 & $\mathbf{0 , 0 1 0}$ \\
\hline \multicolumn{6}{|l|}{ Goodness of Fit Model : } \\
\hline
\end{tabular}

Sumber: Data diolah peneliti (2020)

\section{Hasil Pengujian Pengaruh Langsung}

1. Nilai $p$ value pengaruh brand image terhadap loyalty (BI $\rightarrow$ LOY) adalah sebesar 0,000 dengan $T$ statistik sebesar 4,289 dan koefisien jalur bertanda positif sebesar 0,329. Oleh 
karena nilai $p$ value $<0,05$, T statistik $>1,96$ dan koefisien jalur positif maka dapat disimpulkan bahwa brand image berpengaruh positif dan signifikan terhadap loyalitas pelanggan Ayam Geprek Don. Berdasarkan nilai koefisien jalur sebesar 0,329 juga dapat diperoleh kesimpulan bahwa brand image dapat memberikan kontribusi kepada loyalitas pelanggan Ayam Geprek Don dengan besar kontribusi sebesar 32,9\%. Hasil penelitian ini sejalan dengan hasil penelitian Tan, dkk. (2015) dan Porral \& Levi-Mangin (2016).

2. Nilai $p$ value pengaruh customer satisfaction terhadap loyalty (CUS $\rightarrow$ LOY) adalah sebesar 0,009 dengan $T$ statistik sebesar 2,630 dan koefisien jalur bertanda positif sebesar 0,285 . Oleh karena nilai $p$ value $<0,05, T$ statistik $>1,96$ dan koefsien jalur positif maka dapat disimpulkan bahwa customer satisfaction berpengaruh positif dan signifikan terhadap loyalitas pelanggan Ayam Geprek Don. Berdasarkan nilai koefisien jalur sebesar 0,285 juga dapat diperoleh kesimpulan bahwa customer satisfaction dapat memberikan kontribusi kepada loyalitas pelanggan Ayam Geprek Don dengan besar kontribusi sebesar 28,5\%. Hasil penelitian ini sejalan dengan hasil penelitian Krom (2015) dan Lee \& Jee (2016).

3. Nilai $\mathrm{p}$ value pengaruh brand trust terhadap loyalty (BT $\rightarrow$ LOY) adalah sebesar 0,002 dengan $T$ statistik sebesar 3,078 dan koefisien jalur bertanda positif sebesar 0,301. Oleh karena nilai $p$ value $<0,05, T$ statistik $>1,96$ dan koefsien jalur positif maka dapat disimpulkan bahwa brand trust berpengaruh positif dan signifikan terhadap loyalitas pelanggan Ayam Geprek Don. Berdasarkan nilai koefisien jalur sebesar 0,301 juga dapat diperoleh kesimpulan bahwa brand trust dapat memberikan kontribusi kepada loyalitas pelanggan Ayam Geprek Don dengan besar kontribusi sebesar 30,1\%. Hasil penelitian ini sejalan dengan hasil penelitian Popp, dkk. (2019) dan Chandio,dkk.(2015).

4. Nilai $p$ value pengaruh loyalty terhadap WOM (LOY $\rightarrow$ WOM) adalah sebesar 0,000 dengan $T$ statistik sebesar 15,561 dan koefisien jalur bertanda positif sebesar 0,776. Oleh karena nilai $p$ value $<0,05, T$ statistik $>1,96$ dan koefsien jalur positif maka dapat disimpulkan bahwa loyalitas berpengaruh positif dan signifikan terhadap WOM produk ayam geprek Don. Berdasarkan nilai koefisien jalur sebesar 0,776 juga dapat diperoleh kesimpulan bahwa loyalitas pelanggan dapat memberikan kontribusi kepada WOM produk Ayam Geprek Don dengan besar kontribusi sebesar 77,6\%. Hasil penelitian ini sejalan dengan hasil penelitian Hamza \& Rahul (2017) dan Baig, dkk. (2015).

\section{Hasil Pengujian Pengaruh Tidak Langsung}

Dalam penelitian ini, loyalitas berperan sebagai intervening yang memediasi pengaruh brand image, brand trust dan customer satisfaction terhadap word of mouth produk. Hasil pengujian pengaruh tidak langsung menunjukkan bahwa brand image, brand trust dan customer satisfaction secara tidak langsung dapat berpengaruh terhadap word of mouth dengan dimediasi oleh loyalitas. Tingginya brand image, brand trust dan kepuasan pelanggan akan produk dapat meningkatkan loyalitas yang selanjutnya akan meningkatkan word of mouth produk.

\section{KESIMPULAN DAN SARAN \\ Kesimpulan}

1. Brand image berpengaruh positif dan signifikan terhadap loyalitas pelanggan Ayam Geprek Don.

2. Customer satisfaction berpengaruh positif dan signifikan terhadap loyalitas pelanggan Ayam Geprek Don.

3. Brand trust berpengaruh positif dan signifikan terhadap loyalitas pelanggan Ayam Geprek Don.

4. Loyalitas berpengaruh positif dan signifikan terhadap WOM produk Ayam Geprek Don. 


\section{Saran}

Hasil penelitian menunjukkan bahwa brand image, brand trust, dan customer satisfaction merupakan faktor penting yang berpengaruh terhadap loyalitas dan WOM produk Ayam Geprek Don. Dengan demikian agar produk Ayam Geprek Don semakin meningkat penjualannya maka sebaiknya produk ini terus meningkatkan kepusan pelanggannya membangun brand image lebih baik dan menjaga kepercayaan yang diberikan pelanggan. Adapun saran bagi penelitian selanjutnya, peneliti menambah variabel di luar variabel yang telah diteliti dalam penelitian ini atau dengan melakukan modifikasi model.

\section{DAFTAR PUSTAKA}

Ali, A., dkk. (2018). Antecedents of consumers' halal brand purchase intention: An integrated approach. Management Decision, 56(4), 715-735.

Baig, S. A., dkk. (2015). Mediating roles of customer satisfaction and customer trust in building brand loyalty: An empirical study in Pakistan. Business Management Dynamics, 4(10), 01-29.

Chandio, Z. U., Qureshi, M. A., \& Ahmed, S. (2015). Brand trust, customer satisfaction and brand loyalty - a cross examination. Journal of Business Strategies, 9(1), 63-82.

Choi, B. J., \& Choi, B. J. (2014). The effects of perceived service recovery justice on customer affection, loyalty, and word-of-mouth. European Journal of Marketing, 48(1/2), 108131.

De Matos, C. A., \& Rossi, V. C. A. (2008). Word-of-mouth communications in marketing: A meta-analytic review of the antecedents and moderators. Journal of Academy of Marketing Science, 36(4), 578-596.

Delgado-Ballester, E. (2003). Development and Validation of brand trust scale. Journal of Market Research, 13(1), 1-28.

Ghozali, I. (2016). Structural Equation Modeling, Metode Alternatif dengan Partial Least Square (PLS) (Edisi 4). Semarang: Badan Penerbit Universitas Diponegoro

Hair, J. F. Jr., Black, W. C., Babin, B. J., \& Anderson, R. E. (2014). Multivariate Data Analysis ( $7^{\text {th }}$ ed.). Edinburg: Pearson Education Limited.

Hamza, V. K. \& Rahul, G. (2017). Mediation of brand equity on word of mouth: A study with special reference to customers of fashion products in India. Advances in Management, 10(10).

Harris-Walker, L. J. (2001). The measurement of word-of-mouth communication and an investigation of service quality and customer commitment as potential antecedents. Journal of Service Research, 4(1), 60-75.

Kotler, P. (2006). Marketing Management (12 ${ }^{\text {th }}$ ed.). New Jersey: Pearson Prentice Hall.

Krom, I. (2015). Global online entrepreneurship and the impact of innovation on brands. Emerging Markets Journal, 5(2), 89-101.

Lee, H. J. \& Jee, Y. S. (2016). The impacts of brand asset of domestic screen golf playing systems upon brand trust and brand loyalty. International Journal of Sports Marketing and Sponsorship, 17(4), 320-332.

Popp, B., \& Woratschek, H. (2017). Consumer-brand identification revisited: An integrative framework of brand identification, customer satisfaction, and price image and their role for brand loyalty and word of mouth. Journal of Brand Management, 24(3), 250-270.

Porral, C. C., \& Levy-Mangin, J. P. (2016). Food private label brands: The role of consumer trust on loyalty and purchase intention. British Food Journal, 188(3), 679-696.

Tan, T. M., Ismail, H., \& Devinaga, R. (2015). Malaysian fast food brand equity. The Journal of Developing Areas, 49(5).

Upamannyu, N. K., \& Mathur, G. (2012). Effect of brand trust, brand affect and brand image on customer brand loyalty and consumer brand extension attitude in FMCG sector. PRiMa: Practices and Research in Marketing, 3(2), 1-14. 